\title{
Viability of renewable energies and industrialization of rural areas using high-performance concrete
}

\author{
Daltro Garcia Pinatti ${ }^{1}$, Rosa Ana Conte ${ }^{1}$, Carolina Azevedo Braz ${ }^{2}$, Thiago Hirosse Silva ${ }^{2}$, \\ Felipe da Costa Aparecido ${ }^{1}$ \\ ${ }^{1}$ Department of Materials Engineering \\ ${ }^{2}$ Department of Chemical Engineering \\ Escola de Engenharia de Lorena, Sao Paulo University \\ Polo Urbo Industrial s/no. Gleba AI6 -12602-810 Lorena, SP (Brazil) \\ Phone: +00 5512 31599924, e-mail: pinatti@demar.eel.usp.br, \\ rosaconte@demar.eel.usp.br;c.azevedobraz@gmail.com; thiago.hirosse.silva@usp.br; \\ felipecaparecido@outlook.com
}

\begin{abstract}
In the Tropics, the two biggest sources of renewable energy are the intermittent thermal solar and biomass, which is limited by the occupation of large areas. Highperformance concrete (HPC) allows construction of thermal solar parabolic collectors (TSPC), which collect $70 \%$ of the incident radiation for preheating and evaporating feed water of a Rankine thermoelectric unit whose steam is superheated in a biomass-fired boiler. HPC also allows economical fabrication of stakes, planks to retain rainwater in soil level curves and U-, L-, I- structural profiles to construct riparian tanks to be used for grass irrigation during the dry season increasing biomass production up to 60 tons of dry biomass per hectare per year. Simultaneously soil and fertilizer are recycled recovering degraded bare hills that occupy $1 / 3$ of Brazilian territory. Integration of thermal solar and biomass is complemented with the production of animal protein (cattle, free-range chicken, and fish); anaerobic digester of biomass inoculated with animal deject generates biogas that is washed to vehicular methane gas replacing fossil fuels. Availability of energy (electrical, thermal, and vehicular), water and space below TSPC area promotes transference of urban industries to rural areas.
\end{abstract}

\section{Key words}

Thermal solar-biomass energy generation, anaerobic digester, rainwater retention, high-performance concrete profiles.

\section{Introduction}

A significant portion of the rural area between Capricorn and Cancer tropics is characterized by the presence of the sun, rain, biomass, medium and large declivities (>15\%), degraded soil, and widespread fire during the dry season. In Brazil, those areas, called bare hills, represent $1 / 3$ of the country territory with low-density population, low-income generation, and low perspective of evolution with conventional technologies. The second third is flat territory (declivity $<15 \%$ ) occupied by agribusiness with large machinery operation. The last third is the Amazon region, swamps and flooded territory. We are developing an integrated tropical technology based on the use of highperformance concrete (HPC) for erosion control, rainwater retention, thermal solar collection, biomass production, vehicular methane gas (VMG) fuel from anaerobic digestion (AD) of biomass inoculated with cattle deject, electric energy generation and transference of the urban industry to the rural area (TUIRA).

\section{Objectives}

The daily intermittence of the sun, water and biomass availability (wet and dry season), erosion, and soil degradation are the limitations to amass wealth in the bare hills. HPC solves these limitations, integrates and maximizes the generation of electric, thermal, and vehicular energy from renewable sources, protein production (cattle and poultry), and attracts TUIRA. Those objectives are accomplished treating materials, space, soil, topography, water, thermal solar energy, biomass, food, electricity, steam, heat, fuel as an integration of tropical energies (ITE), but they are difficult to be achieved in temperate and cold regions of the planet.

\section{Thermal solar-biomass renewable technology thermoelectric unit (TEU)}

Main components of TEU are: thermal solar parabolic collector (TSPC), boiler, steam turbine, and dryer condenser silo. For lower power capacity biomass area is small and TSPC area is large; for higher power capacity it is the opposite. The smallest TEU has $1.0 \mathrm{MW}_{\mathrm{e}}, 6.8 \mathrm{t}$ of steam per hour, 4.0 $\mathrm{MPa}, 320 \mathrm{C}, 0.013 \mathrm{MPa}$ turbine exhaust pressure, $23 \%$ thermodynamic efficiency, $4.35 \mathrm{MW}_{\mathrm{t}}$ of thermal energy split into $0.60 \mathrm{MW}_{\mathrm{t}}$ coming from biomass (7.5 ha of grass) ${ }^{(a)}$ and $3.75 \mathrm{MW}_{\mathrm{t}}$ from TSPC $(1.3 \mathrm{ha})^{(\mathrm{b})}$ (see Further Information for all calculations from (a) to (o)). Initially, TEU will operate $7 \mathrm{~h}$ per day increasing with the TSPC area and the installation of a hydro storage of thermal energy (HSTE) unit. In 
Brazil maximum of $1 \mathrm{MW}_{\mathrm{e}}$ of power generation is allowed for connection to $13.8 \mathrm{kV}$ distribution network by a bidirectional meter.

Firetube boiler with external biomass combustion, superheater, dimensions of $\mathrm{L} \times \mathrm{W} \times \mathrm{H}=9.0 \mathrm{~m} \times 3.2 \mathrm{~m} \mathrm{x}$ $4.2 \mathrm{~m}$ and weight of 30 tons are commercially available for pressures up to 3.0 $\mathrm{MPa}$. Pressure increase to 4.0 $\mathrm{MPa}$ and admission of two-phase fluid (water-steam) from TSPC is under negotiation with boiler industries. The limitation is the steel cylindrical shell to support the pressure at medium temperature. The solution is its replacement by double wall reinforced HPC thick shell with an external layer of calcium silicate concrete with active silica and an internal layer with silica-alumina refractory concrete. Radial pressure is supported by 400 spring wires of $\varnothing 5 \mathrm{~mm}, \sigma=1,660 \mathrm{MPa}$ per meter of boiler HPC shell ${ }^{(\mathrm{c})}$. The axial pressure at the lids is supported by a $24 \mathrm{~mm}$ (1") thickness steel shell welded in terminal flanges cast in the $\mathrm{HPC}^{(\mathrm{d})}$. A corrugated small thickness internal stainless steel shell maintains the concrete dry and together with the external steel shell is the preform for 'concrete pouring'.

Dryer condenser silo (DCS) with $\mathrm{L} \times \mathrm{W} \times \mathrm{H}=15 \mathrm{~m} \times$ $7.8 \mathrm{~m} \times 5 \mathrm{~m}\left(585 \mathrm{~m}^{3}\right)$, feeding biomass density $125 \mathrm{~kg} / \mathrm{m}^{3}$, is sufficient to store $73,125 \mathrm{~kg}$. At a biomass consumption rate of $117.5 \mathrm{~kg} / \mathrm{h}$ during $7 \mathrm{~h} / \mathrm{day}$, the stored biomass will last 89 days. Details of DCS are published elsewhere [1]. DCS is composed of following parts: conic bottom with extraction screw and feeding of combustion gas coming from chimney; two feeding distribution screws at the top with ventilation fans; turbine exhaustion steam condensation in radiators installed at the vertical parts of the DCS walls. Fans suck the combustion and partially recirculate it to the condensers; below the conic parts of the condenser air plus combustion gas recirculation is replaced by water spray to guarantee complete condensation.

\section{Description of the ITE technology}

The main material, which is the basis of the technology, is high-performance concrete (HPC) with the addition of active silica produced in fluidized bed combustion boiler [2], or calcined kaolinitic clay [3]. Compression resistance reaches $90 \mathrm{MPa}$, three times higher than the value of $30 \mathrm{MPa}$ concrete. The average mechanical, corrosion and erosion resistance, impermeabilization and low cost of HPC is the first bridge to overcome the Death Valley between bare hill problems and competitive cost of the electrical, thermal, vehicular energy, and animal protein generated by other technologies. Fig. 1 shows the block diagram of the production of HPC profiles, their use for renewable energy generation to be supplied for industrialization of rural areas.

The first line of blocks 1 to 7 indicates the profiles prefabricated at the HPC mini-factory $\left(3 \mathrm{~m}^{3}\right.$ of HPC/day). The profiles of blocks 1 to 3 are used to construct the products of blocks 8 to 11 , which allow a high rate of biomass production (12), retention of rainwater, erosion contention, and thermal solar collection. The above actions along with fertilization recover degraded bare hills through grass production. Profiles of blocks 3 and 4 are used to construct tanking products (13 riparian tanks, 14 $\mathrm{AD}$, and 15 silos). Preheated water by TSPC feeds the make-up for TEU boiler (16) that also burns biomass to evaporate and superheat the steam. At night the boiler operates only with biomass. Riparian tanks and AD supply water for irrigation (17) (biomass production); part of purified water is fed to TEU and to biogas washing to obtain VMG (18). Prestressed HPC high-pressure vessel (5) is used as a stationary tank of VMG virtual gas station (19). Blocks 20, 21, 22 refer to profiles application in roads. Waste and effluents of ITE (23) are treated and reused. Pumps, rural industry and TUIRA (24) will convert energy (electrical and steam) into higher value products (meat, HPC profiles, recycled plastics, etc.).

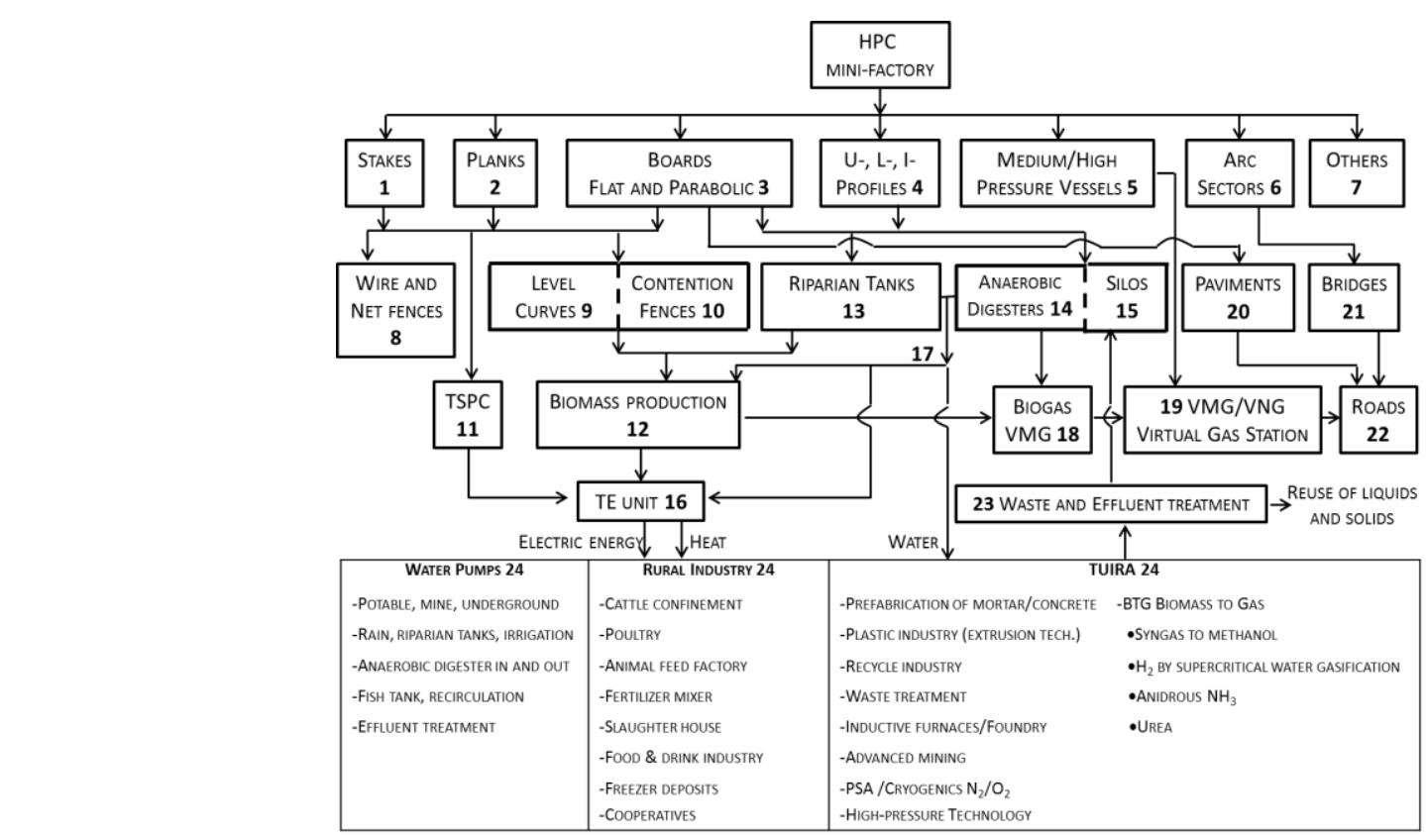

Fig. 1. Block diagram of ITE technology. 


\section{A. Materials, structural profiles, and main edifications}

The first technology to be established is a mini-factory of reinforced HPC structural profiles and vessels denominated PERCADs. HPC stakes are used to construct wired and net fences for Voisin double rotational grazing system for poultry and cattle. Boards, U- and L-profiles are used in riparian tanks for storage of rain and pumped underground water, ADs of $5,832 \mathrm{~m}^{3}$, fish tanks, and other constructions. Level curves and contention fences for erosion control, rainwater retention (increasing soil water absorption and draining the rainwater excess to riparian tanks) are constructed with HPC stakes, planks, and boards. Level curves, riparian tanks, and drip irrigation avoid flooding, retain more water in the soil than the original forest, regularize the hydric balance of the groundwater table, creeks and rivers, and recirculate soil and fertilizers. The hydric deficit for grass growing in the dry season is $350 \mathrm{~mm}$ ( $25 \%$ of year precipitation, leaving $75 \%$ for other uses or eventually flood). The water needed for two hectares is $7,000 \mathrm{~m}^{3(\mathrm{e})}$ supplied by one riparian tank $\left(5,832 \mathrm{~m}^{3}\right)$ supplemented by underground pumped water.

PERCADs allow construction of a key construction to the proposed technology that is the AD up to the same size of riparian tanks with the following process optimizations: slurry with $15 \%$ of dry matter (DM), agitation, two stages of temperature (mesophilic at $35 \mathrm{C}$ and thermophilic at $55 \mathrm{C}$ ), recovery of microorganism, inoculation with cattle deject. Three products are generated: biogas to be purified to $\mathrm{VMG}$, liquid to fertigation, and undigested sludge to be dried to powder and used as fuel in the TEU. Biogas $(55 \%$ $\mathrm{CH}_{4}$ ) production reaches $160 \mathrm{~m}^{3}$ per dry ton of biomass (TDB) in a 60-day hydraulic retention time. High digestibility grass produced by double Voisin rotation generates energy per hectare (VMG plus electricity) larger than sugarcane ethanol and soy biodiesel. Silos with similar construction as the AD but with a height up to $9 \mathrm{~m}$ can be used to store grains and other products with densities up to $500 \mathrm{~kg} / \mathrm{m}^{3}$.

\section{B. Biomass production}

Biomass supply in meaningful volumes and low cost without competition with food production are the main limitations for generation of renewable energy. Maximum present rates of biomass production reach 40 tons of dry biomass per hectare per year with cloned eucalyptus or elephant grass. It is possible to achieve 60 tons of dry grass per hectare per year by using double Voisin system, fertilization, and irrigation. Distribution of that biomass would be $1 / 3$ for growing 1,000 free-range chickens per hectare per year eating shoots after grass cutting; $1 / 3$ for 6 heads of cattle per hectare per year supplemented with $2 \mathrm{~kg}$ per day per head of low-cost wheat and corn residues, and $1 / 3$ for biomass supply to the AD.

\section{Thermal solar parabolic collector (TSPC)}

The major source of energy to preheat the TEU feed water, and eventually its partial evaporation, is the thermal solar energy; biomass is only a complement to evaporate the water and superheat the steam. TSPC is composed of an HPC parabolic board coated with reflective inox foil, a metallic focal tube with selective coating concentric to a borosilicate tube for thermal insulation [1]. A roof truss spaced by $2.6 \mathrm{~m}$ and spaned up to $36 \mathrm{~m}$ supports the TSPC. The space below TSPC is occupied by other activities like residential, commercial or industrial buildings that cover the major cost of the installations. Typical average solar collection is $44.15 \times 10^{6} \mathrm{MJ}_{\mathrm{t}} / \mathrm{ha} \mathrm{yr}^{(\mathrm{f})}$. The energy collected by cloned eucalyptus forest is $736 \times 10^{3} \mathrm{MJ}_{\mathrm{t}} / \mathrm{ha}^{\mathrm{yr}} \mathrm{g}^{\mathrm{g})}$, therefore TSPC is equivalent to 60 times the biomass area, which is slightly reduced by locally cloudy sky days. Thermal solar-biomass integration with the use of PERCADs solves at one stroke all major problems of both energy sources.

\section{Contribution of thermal sources to TEU}

Fig. 2, dashed line, shows the Rankine cycle thermal efficiency of a TEU without the contribution of economizer, air preheater, and reheating for two-stage turbine expansion, as a function of pressure and temperature. Thermal efficiency does not depend on the type of energy source (thermal solar and biomass). Curves 1 and 2 of the same figure show the contribution of TSPC to preheat the water up to saturation and biomass for evaporation and superheating the steam. The contribution of TSPC is smaller than biomass, which demands high green area (reforestation or grass). The pair of curves 3 and 4 shows the hypothesis where the TSPC area is sufficient to generate saturated steam; biomass contribution is only to superheat the steam resulting in a small green area and large TSPC area to be occupied by TUIRA or by large cattle confinements. The evaporator section of TSPC works as an inclined water wall of a boiler with a water feeding pipe placed at the lower part of the roof truss. A collector pipe at the upper part separates steam (that flows to the boiler) and saturated water, that is partially recycled together with the make-up water to the feeding pipe of TSPC.

The proposed ITE claims for modular TEU as the TSPC area increases and shows that biomass is no longer the limiting factor for TSPC-biomass renewable energy generation. The mixed generation of TSPC and biomass is simplified when a firetube boiler is used with an external biomass burner with watertube walls at the lower section and steam superheating at the upper section coupled to a steam turbine able to generate $(2 \pm 0.5) \mathrm{MW}$. A cyclone is installed between burner and boiler. The boiler is a heat exchanger, which receives from TSPC preheated saturated water in the make-up water and saturated steam in the drum coupled to the superheater. Watertube boiler with fluidized bed combustor (10 MW class) burning dry biomass (LHV $18.4 \mathrm{MJ} / \mathrm{kg}$ ) and receiving preheated water from TSPC make it difficult the optimization of temperatures in the burner, secondary combustion, economizer, and air preheating. Boiler manufacturer has solved this problem installing a diaphragm valve after the economizer to derive part of hot combustion gas to other applications. 


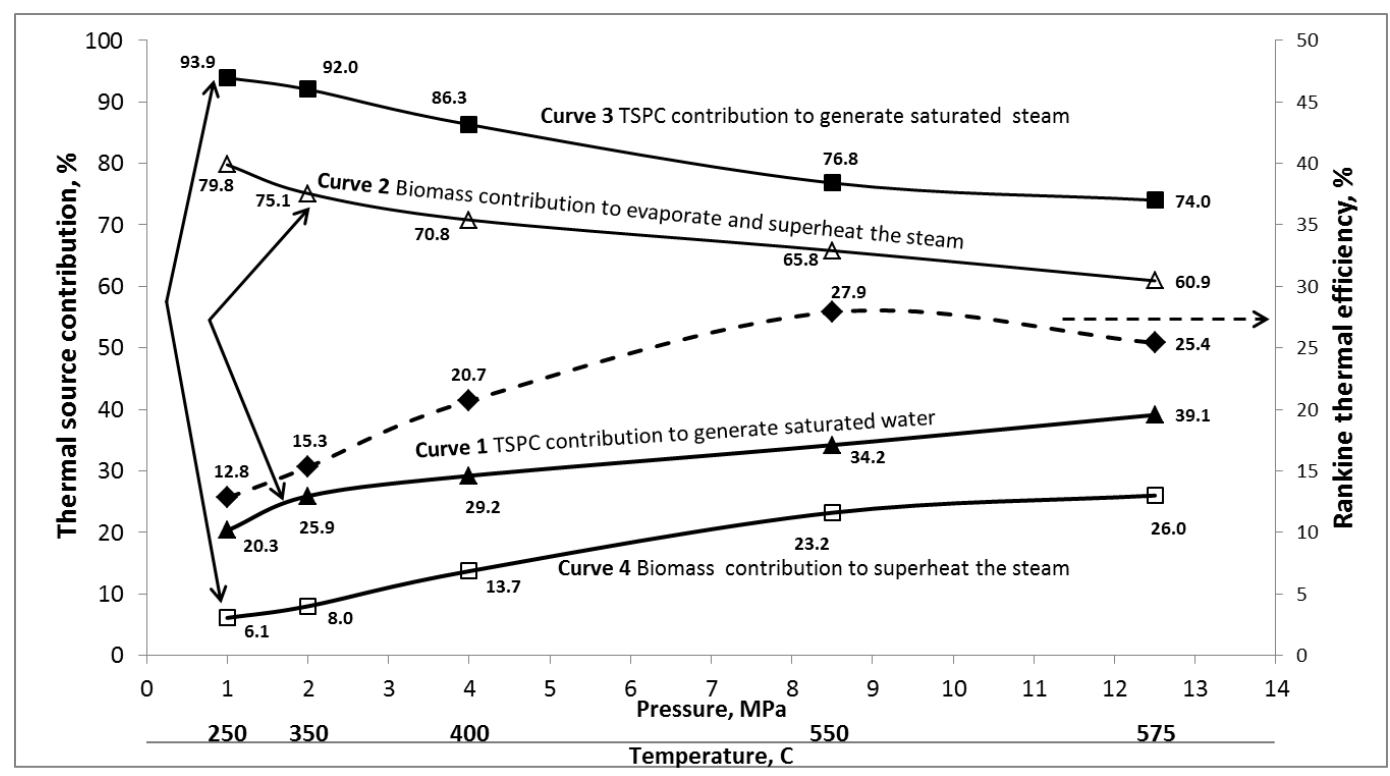

Fig. 2. Rankine cycle efficiency and thermal sources contribution as a function of TEU pressure and temperature.

\section{E. Energy storage and degree of redundancy}

Energy storage and redundancy are intrinsic to ITE technology. A medium-pressure vessel (4 MPa, $250 \mathrm{C}$ ) made of prestressed HPC cylinder (block 5, fig. 1) thermally insulated with an internal cylinder of refractory concrete is used as hydro storage of thermal energy (HSTE). HPC is prestressed with spring wire $(2,000 \mathrm{MPa})$. Heated water from TSPC, which is not consumed in the boiler, is stored in the HSTE and consumed after sunset. The HSTE maximizes thermal solar energy usage and minimizes biomass consumption during the night period. ITE has a triple redundancy in the electric energy supply: first, at the TEU; second, at the engine generator set, whose capacity can be enlarged for short periods using VMG stored in the HPC high-pressure vessel, and third, at the $13.8 \mathrm{kV}$ network bidirectional meter, which is limited to $1 \mathrm{MW}$ for dispatching but unlimited for the reception.

\section{F. Transference of urban industries to rural areas (TUIRA)}

Electric energy is a bad product for commercialization because it has a low price to sell and it is expensive to buy. Transmission, distribution, losses, rates, and taxes are the major part of costs. Besides energy (electrical, thermal, and vehicular) TUIRA offers the availability of space, water supply, effluent treatment, residence, logistic, sharing services, etc. Besides rural type industries (cattle, poultry, cooperatives, food and drinking industry, animal feed factory, fertilizer mixers, slaughterhouse, freezer deposits) some examples of TUIRA are waste treatment, plastic (extrusion technology) and recycling industry, foundry (induction heating), prefabrication of concrete artifacts, industrial consumers of biogas, methane, syngas, and hydrogen, showing a high probability of occupation of the space below TSPCs. The average power rate per ha of a hydroelectric reservoir is $5 \mathrm{~kW}$ per hectare of the flooded area; the photovoltaic farm has a rate of $10 \mathrm{~kW}$ per hectare and TSPC up to steam evaporation plus biomass can reach $1,000 \mathrm{~kW}$ per hectare. The first technology is moving into exhaustion; the last one has an almost infinite potential in the tropics.

\section{TECSITE - Pilot plant technological site: execution and prospects}

TECSITE establishment was preceded by a decade of development work on active rice husk silica and active quartzite kaolinitic clay to have a large-scale supply of low-cost active silica and clay for HPC production. The present scale of silica fumes production as a by-product of metallurgical silicon is two orders of magnitude smaller than cement industry demand, which blocks the large scale production of HPC.

A pilot plant technological site is under construction to create a second bridge to overcome the Death Valley between the innovation (integration of HPC, TSPC, biomass, medium to high-pressure vessels, eolic energy in the future) and the market [4]. Fig. 3 shows part of the TECSITE (9 ha) where most of the pilot plants are under installation. It is a radical innovation with small chance to obtain public financing. TECSITE is being established with private funds. The lack of funding opens the opportunity to explore the self-finance capacity of TECSITE, for example, by fabrication of HPC stakes, planks, boards and $U$ structural profiles in the minifactory for self-consumption to build pens for poultry growth and cattle semi-confinement.

Level curves made with stakes and planks are spaced by $20 \mathrm{~m}$ and they receive drip irrigation during the dry season eliminating the hydric deficit. The water excess flows to the riparian tanks. With irrigation, fertilization, double Voisin rotation of cattle, poultry, grass cutting and biomass production of $60 \mathrm{TDB}$ per ha per year the revenue will reach USD 25,000.00 per hectare per year that is ten times bigger than grains in large agribusiness. Cut grass for semi-confinement mixed with cattle deject (slurry with $15 \%$ of dry mass) feeds two ADs of $648 \mathrm{~m}^{3}$ generating $15,552 \mathrm{Nm}^{3}$ of $55 \% \mathrm{CH}_{4}$ biogas every 
60 days $^{(\text {h) }}$. At a Brazilian VMG price (USD 0.50/ $\mathrm{Nm}^{3}$ ) its value is USD $25,660.00$ per year ${ }^{(i)}$. If biogas fuels an engine generator set the avoided electricity value at USD $0.15 / \mathrm{kWh}_{\mathrm{e}}$ is USD 21,555.00 per year ${ }^{(\mathrm{j})}$. Split between both uses is an operational decision. Besides biogas anaerobic digestion produces liquid for fertigation and sludge (undigested biomass) that, after drying and grinding, is burned in a powder burner in the boiler or converted into syngas as fuel for the engine generator set. Initial TSPC area is $1,800 \mathrm{~m}^{2}$ below which can be installed pen, grass grinding machines, dryer condenser silo, TEU,

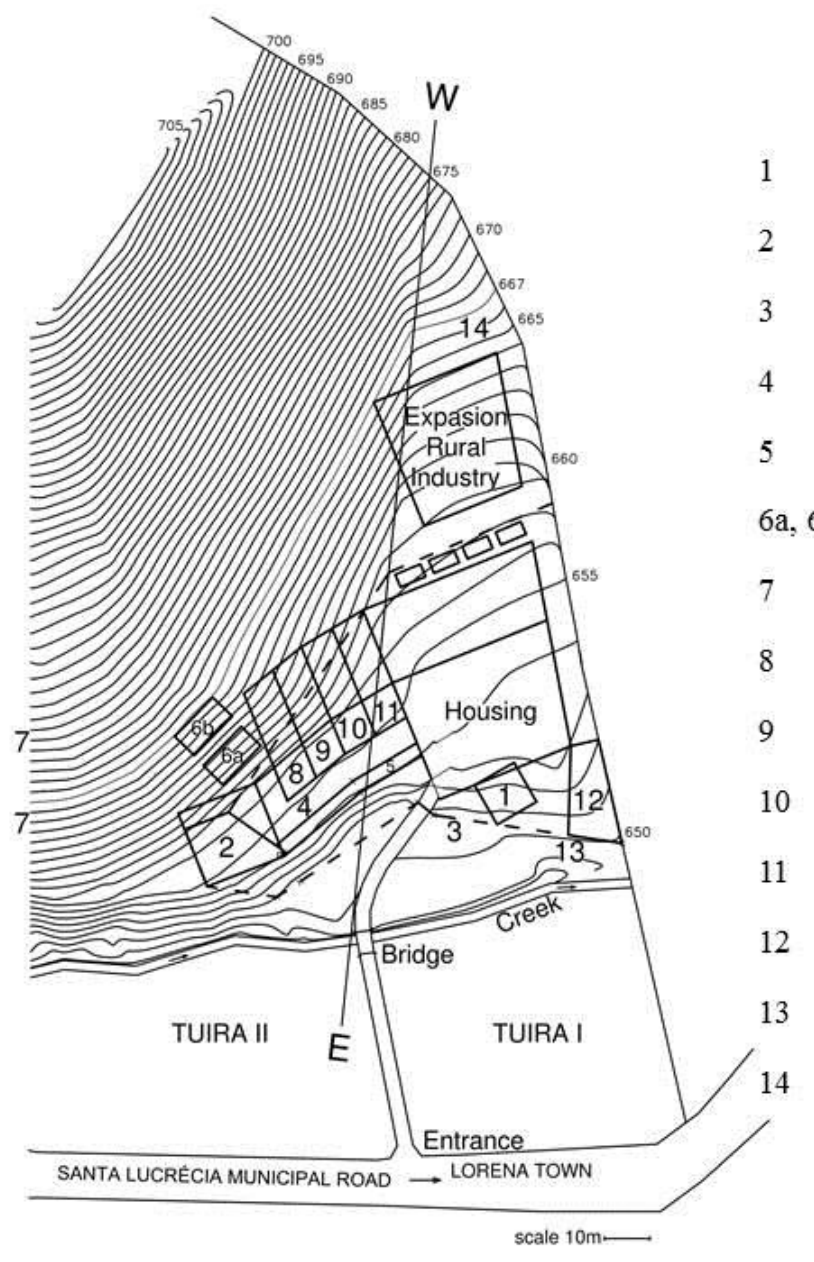

Fig. 3. TECSITE - Pilot plant technological site: execution and prospects.

\section{Further Information}

(a) Biomass source $(\mathrm{LHV}=18.4 \mathrm{MJ} / \mathrm{kg})$ : $(0.60 \mathrm{MW}) / 18.4 \mathrm{MJ} / \mathrm{kg})=0.0326 \mathrm{~kg} / \mathrm{s}=117.4 \mathrm{~kg} / \mathrm{h}=$ $0.117 \mathrm{TDB} / \mathrm{h}=0.822 \mathrm{TDB} /$ day of $7 \mathrm{~h}=300 \mathrm{TDB} / \mathrm{yr}=$ 7.5 ha $x 40 \mathrm{TDB} / \mathrm{ha}$.yr. Operation up to $21 \mathrm{~h} /$ day is possible receiving biomass from an external source aiming to stimulate greening and avoid widespread country fire during dry season.

(b) Area (A) of TSPC source: $3.75 \mathrm{MW}_{\mathrm{t}} \mathrm{x} 7 \mathrm{~h} /$ day $=\mathrm{A} \mathrm{x}$ $4.8 \quad \mathrm{kWh}_{\mathrm{t}} / \mathrm{m}^{2}$.day (average insolation) $\mathrm{x} \quad 70 \%$ (TSPC collecting efficiency [5]) x 60\% (clear days); $\mathrm{A}=$ $13,021 \mathrm{~m}^{2}=1.3 \mathrm{ha}$. Until this area triples by TUIRA TSPC will generate two-phase fluid. industrial kitchen, storage rooms, hardware room, and employees' apartments. TSPC is incrementally installed and adjusted to the terrain topography.

Industrial kitchen licensed by health authorities for chicken and fish processing such as slaughter, cleaning, packing, freezing, distribution to clients will partially operate in food preparation for direct delivery to the consumer; it has the support of electrical energy, steam, freezing, and effluent treatment infrastructure.

PERCAD mini factory: operational

Pen for cattle semi-confinement: operational

Fences of first picket for poultry growth: operational

Street: operational

Service facilities: operational

, $6 \mathrm{~b}$ Anaerobic digesters: under construction

Level curves: under construction

Hen for poultry: under construction

Dryer condenser silo: under construction

$1 \mathrm{MW}_{\mathrm{e}} \mathrm{TEU}$ : under construction

Industrial kitchen: under construction

Riparian tank: under construction

Water mine: operational

Water tank: operational (c) Force on the external shell due to $7.2 \mathrm{MPa}$ $(1.8 \times 4.0 \mathrm{MPa}): \mathrm{F}=\mathrm{PD} / 2=(7.2 \mathrm{MPa} \times 3.2 \mathrm{~m}) / 2=$ $11.52 \mathrm{MN} / \mathrm{m}$; Force supported by a spring wire $\varnothing 5 \mathrm{~mm}$, $\sigma=1,660 \mathrm{MPa}:(\pi / 4)(0.005)^{2} \times 1,660 \mathrm{MPa}=32,575.50 \mathrm{~N}$; number of spring wires to support the pressure force on the external shell: $(11.52 \mathrm{MN} / \mathrm{m}) / 32,575.50 \mathrm{~N}=$ 354 wires $/ \mathrm{m}$ (assembled in 8 layers of 50 wires $/ \mathrm{m}$ (400 wires) tied to a net of CA60 $\varnothing 4.2 \mathrm{~mm} 100 \mathrm{~mm} \mathrm{x}$ $100 \mathrm{~mm}$.

(d) Axial force due to pressure at the two lids of the boiler: $(\pi / 4)(3.6)^{2}$ x 7.2 MPa $=73.25 \mathrm{MN}$; thickness $(\mathrm{t})$ of external steel shell of the boiler $(\sigma=240 \mathrm{MPa})$ : $73.25 \mathrm{MN}=\pi \times 4.0 \mathrm{~m}(\mathrm{t}) \times 240 \mathrm{MPa} ; \mathrm{t}=0.024 \mathrm{~m}(1$ '). 
(e) Water needed for 2 ha: $0.35 \mathrm{~m} \mathrm{x} \mathrm{10,000} \mathrm{m}^{2} / \mathrm{ha} \times 2$ ha $=$ $7,000 \mathrm{~m}^{3}$.

(f) Thermal solar collection with irradiation of $4.8 \mathrm{kWh} / \mathrm{m}^{2}$.day with $70 \%$ of collecting efficiency $=$ $4.8 \mathrm{kWh} / \mathrm{m}^{2}$.day $\times 70 \% \times 10,000 \mathrm{~m}^{2} /$ ha $\times 365$ days $/ \mathrm{yr}=$ $12,264 \mathrm{MWh}_{\mathrm{t}} /$ ha.yr $=44.15 \times 10^{6} \mathrm{MJ}_{\mathrm{t}} /$ ha.yr.

(g) Biomass energy collection $=40$ TDB/ha.yr $\mathrm{x}$ 18.4 MJ/kg DB $=736 \times 10^{3} \mathrm{MJ}_{\mathrm{t}} / \mathrm{ha}$.yr.

(h) Biogas production by two anaerobic digesters: $2(\mathrm{~L} \times \mathrm{W} \times \mathrm{H})=2(12 \mathrm{~m} \times 6 \mathrm{~m} \times 4.5 \mathrm{~m})=2 \times 324 \mathrm{~m}^{3}=$ $48 \mathrm{~m}^{3} ; 648 \mathrm{~m}^{3} \times 15 \% \mathrm{DM} \times 160 \mathrm{Nm}^{3}$ of biogas/TDM = $15,552 \mathrm{Nm}^{3}$ of $55 \% \mathrm{CH}_{4}$ biogas every 60 days.

(i) VMG value/yr: $15,552 \mathrm{Nm}^{3}$ of biogas/60 days x $55 \%$ $\mathrm{CH}_{4} \times 6$ cycles/yr $\mathrm{x}$ USD $0.50 / \mathrm{Nm}^{3}$ of $\mathrm{VMG}=$ USD 25,661.00/yr.

(j) Value of avoided cost of electricity by the engine generator set: $1.54 \mathrm{~kW} /\left(\mathrm{Nm}^{3}\right.$ of biogas $\left./ \mathrm{h}\right) \times 15,552 \mathrm{Nm}^{3}$ of biogas $/ 60$ days $\times 6$ cycles/day $\times$ USD $0.15 / \mathrm{kWh}=$ USD 21,555.00/yr.

(k) Value of electric energy: 1 MW x 24 h/day x 365 days/yr $\times 18 \%$ power factor $\times$ USD $70.00 / \mathrm{MWh} \approx$ USD 500,000.00/yr.

(1) Value of poultry: 1,000 sold units/ha $\mathrm{yr} \times 7$ ha $\mathrm{x}$ USD 5.00/unit = USD 35,000.00/yr.

(m) Value of cattle: 2 sold heads/ha yr x $500 \mathrm{~kg} / \mathrm{head} \mathrm{x}$ 7 ha $x$ USD 3.00/kg = USD 21,000.00/yr.

(n) Value of fish: 5 tanks $\times 20 \mathrm{~m}^{3} / \operatorname{tank} \times 150$ fishes $/ \mathrm{m}^{3} \mathrm{x}$ USD 3.00/fish $=$ USD 45,000.00/yr.

(o) Value of PERCADs: $3 \mathrm{~m}^{3}$ of HPC/day $\mathrm{x}$ 22 days/month $\times 12$ months/yr $\times$ USD $800.00 / \mathrm{m}^{3} \approx$ USD 634,000.00/yr.

\section{Conclusion}

The group of opportunities described above maximizes energy generation, economic results, and environmental quality (soil, water, air, etc.). For small projects, rural industry contribution is large, and TUIRA is small; for large projects, it is the opposite. Commercial projects of $10 \mathrm{MW}_{\mathrm{e}}$ TEU capacity (minimum power to generate competitive energy with hydroelectricity) and $30 \mathrm{MW}_{\mathrm{e}}$ (maximum power with government incentive for distributed electric energy generation to be commercialized in the free market, approx. USD 70.00/MWh) are under negotiation with various investors. Above $30 \mathrm{MW}_{\mathrm{e}}$ commercialization occurs with larger generators by public bidding at approximately USD 30.00/MWh.

The Brazilian population is 210 million inhabitants producing 240 million tons per year of grains and has 220 million heads of cattle resulting in 1 ton per year of grain and 1 head of cattle per inhabitant. The average grain price in the field is USD 350.00 per ton; cattle selling are $1 / 3$ of the head of cattle at a price of USD 1,500.00 per head resulting in USD 500.00 per inhabitant. Large agribusiness generates a wealth of USD 850.00 per inhabitant per year. The major part is not retained in the country (machine and transgenic technology importation, fertilizers, insecticide, a large part of fossil fuel, etc.).

TECSITE figures of renewable energy generation and industrialization of rural areas described in the text generate: USD 500,000.00 per year from electric energy (at a selling price of USD 70.00/MWh) ${ }^{(\mathrm{k})}$; USD 25,660.00 per year from $\mathrm{VMG}^{(\mathrm{i})}$; USD 35,000.00 per year from free-range chicken ${ }^{(1)}$; USD 21,000.00 per year from cattle ${ }^{(\mathrm{m})}$; USD 45,000.00 per year from fish (intensive tilapia growth) ${ }^{(\mathrm{n})}$; USD $634,000.00$ per year from PERCADs ${ }^{(0)}$ totalizing USD 1,260,260.00 per year employing 25 families (100 inhabitants) resulting in USD $12,600.00$ per year per inhabitant, which is 15 times larger than big agribusiness with the advantage of retention of the wealth in the country.

HPC generates the higher revenue because it is the main innovation; electric energy is the second revenue because the sun is the primary energy source. Besides their revenue other contributions solve the intermittency of solar energy through the correct use of soil and water, and fertilizer recycling to generate the biomass.

\section{Acknowledgement}

The authors wish to thank the valued contribution of our undergraduate students in the execution of basic projects. The authors also thank Araguaia Ambiental Ltd. and Mineração São João Batista Ltd. to the partial financial support to establish ITE technologies.

\section{References.}

[1] R.A. Conte, D.G. Pinatti, L.F.M. Marton, S. Ribeiro, T.W. Acosta, R.A.P.A. Cruz, and H.F. Santiago, "Parabolic Solar Collector Coverage made of High-performance Concrete with Addition of Active Rice Husk Silica Integrated to a Biomass Thermoelectric Unit", Key Engineering Materials, v 634, 2015, p.72-82.

[2] D.G. Pinatti, L.F.M. Marton and O. Pilecco, "Production process of fluidized rice husk silica and corresponding resulting product", Brazilian PI 1101915-8 A2, 2012, 35p.

[3] T.R. Toledo, D.G. Pinatti, R.A. Conte, R.C.M. Botti, S. Ribeiro, J.P.R. Laurindo, "Calcined kaolinitic clay from primary sand mining and its application in high performance concrete (HPC)", in Proc. 59 Brazilian Congress on Ceramics CBC2015, pp. 199-210.

[4] D.G. Pinatti and R.A. Conte, "Total integration of renewable and fossil energy aiming to a clean and sustainable energy system", Journal of Energy and Power Engineering, v.7 (no. 1), 2013, 58-65.

[5] S.R. Mattos, "Cylindrical parabolic solar collector analysis, optimization, and performance evaluation", Dissertation (Master degree on Mechanical Engineering), 2011, Guaratinguetá Engineering College, Guaratinguetá, 108 p. 